\title{
Akustické vlastnosti koncertných priestorov vybraných slovenských synagóg v Prešove a Košiciach
}

\section{Michal Jarabica}

Územie Slovenskej republiky má bohatú históriu. Vzhladom na svoju polohu v európskom priestore bolo križovatkou mnohých kultúrnych, náboženských, ideologických a spoločenských prúdov. Tie formovali všetky aspekty života komunít žijúcich na tomto území. Jednotlivé spoločenstvá prostredníctvom vzájomnej interakcie vytvárali regionálne špecifiká urbanizácie. Vd’aka týmto komplexným procesom sa na Slovensku dnes nachádza mnoho historických pamiatok svetového významu. Ich osudy sú rovnako pestré ako osudy komunít, ktoré ich vybudovali a zanechali v nich svoj odkaz.

Niektoré architektonické pamiatky sú vo vel'mi dobrom zachovalom stave, iné sú na pokraji zániku. Vojnové udalosti prvej polovice 20. storočia spustili celosvetovú iniciatívu na ochranu a zachovanie kultúrneho dedičstva. Hlavne v oblasti zachovania architektonických pamiatok však Slovensko dlhodobo zaostávalo. Až posledných pár dekád sa situácia začala zlepšovat'. Ochrana a zachovanie hmotného kultúrneho dedičstva sú finančne, technicky a personálne náročné. V súčasnej situácii je vel'kou výhodou, ak sa v rámci problematiky uchovania historických objektov vyvíjajú aktivity, ktoré pomáhajú generovat’ kapitál na ich údržbu a zachovanie pre budúcnost'. Stavby ako divadlá, operné domy, koncertné sály, ale aj sakrálne objekty sú zároveň nositelmi hodnôt nehmotného kultúrneho dedičstva. Akustické vlastnosti týchto objektov sú typickým príkladom tejto formy kultúrneho dedičstva. Na Slovensku sa stáva trendom transformácia kultúrnych pamiatok, ktoré z rôznych dôvodov neslúžia svojmu pôvodnému účelu, na kultúrne inštitúcie s alternatívnym zameraním, napríklad koncertné sály. V niektorých prípadoch ide len o rozšírenie pôvodnej funkcie, ale objavuje sa čoraz viac objektov, ktoré vd’aka svojim vlastnostiam nachádzajú nové uplatnenie.

Výskum priestorovej akustiky v týchto súvislostiach plní viacero dôležitých úloh. Ak sa priestor nachádza v pôvodnom stave, tak mapuje jeho originálne akustické vlast- 
nosti. Tým vzniká unikátny akustický profil, ktorý sa považuje za autentickú nehmotnú kultúrnu pamiatku. Súčasne dopĺña ostatné výskumné aktivity, čím prispieva ku komplexnému poznaniu daného objektu. Dáta akustických meraní slúžia na identifikovanie problémov, ktoré je následne možné odstránit’ vhodnými akustickými úpravami interiéru. V prípade historických sál slúžia dáta konkrétnych parametrov na optimalizáciu hudobnej dramaturgie. Skvalitnením umeleckého zážitku sa potom zvyšuje ich popularita. V neposlednom rade akustické profily a dáta prispievajú do svetovej databázy, ktorá pomáha akcelerovat' napredovanie tohto vedného odboru a ním skúmaných javov. Jednou z najväčších výhod je možnost' simulácie akustických podmienok konkrétnych priestorov pomocou špecializovaných dozvukových softvérov. V prípade zničenia historickej kultúrnej pamiatky tak môže jej jedinečný akustický profil existovat' d’alej.

Vo svete sa už realizovalo mnoho výskumov tohto druhu. Stredobodom záujmu sú pochopitel'ne priestory s najnáročnejšími požiadavkami na akustickú kvalitu. K najvýznamnejším monografiám zaoberajúcim sa touto problematikou patria diela Lea Beranka Concert Halls and Opera Houses: Music, Acoustics and Architecture 1 a Michaela Barrona Auditorium Acoustics and Architectural Design, ${ }^{2}$ ktoré vel'mi podrobne definujú parametre a vyhodnocovanie priestorovej akustiky. Zároveň prinášajú prehlad meraní významných historických stavieb hudobného zamerania. Rozsiahlemu výskumu sakrálnych stavieb sa venuje Francesco Martellotta, ktorý je spoluautorom článku Guidelines for acoustical measurements in churches. ${ }^{3} \mathrm{~V}$ ňom zhrnul odporúčania pre unifikovaný metodický postup meraní sakrálnych priestorov. Vel'mi dobre spracovaný historický vývoj divadiel, operných domov a koncertných sál ponúka monografia od Victorie Newhouseovej Site and Sound: The architecture and acoustics of new opera houses and concert halls. ${ }^{4}$

Dôvodom, prečo sme sa rozhodli pre spracovanie tejto témy, je aktuálny vývoj v Slovenskej republike uvedený vyššie. Súčasne prebiehajúca transformácia historických sakrálnych budov na koncertné sály alebo minimálne rozšírenie ich funkcionality týmto smerom je ideálnou príležitost'ou zdokumentovat’ tento proces v reálnom čase. Zároveň vzniká možnost' preskúmať širšie okolnosti a podmienky vzniku skúmaných stavieb.

Hlavným ciel’om je poukázat' na dôležitost' priestorovej akustiky ako súčasti komplexného výskumu historických budov a predstavit' jej výhody v rámci zachovania nehmotného kultúrneho dedičstva.

\section{Ochrana a uchovanie kultúrneho dedičstva prostredníctvom výskumu priestorovej akustiky}

Udalosti druhej svetovej vojny mali výrazný dopad na všetky oblasti života v globálnom rozsahu. Negatívne následky v oblasti umenia a kultúrnych pamiatok boli obrovské, mnohé významné zbierky umenia, historické archívy a architektonické pamiatky boli nenávratne zničené. Za mnohé uved’me príklad londýnskej koncertnej sály The Queen's Hall, ktorá bola povestná svojou vynikajúcou akustikou. V čase najväčšej slávy bola považovaná za hudobné centrum britského impéria a vystupovali tu osobnosti ako Claude Debussy, Edward Elgar, Maurice Ravel alebo Richard Strauss. V 30. rokoch 20. storočia sa stala hlavnou sálou Londýnskeho filharmonického orchestra a Symfonického orchestra BBC. Počas druhej svetovej vojny bola v roku 1941 zničená zápalnými bombami pri nemeckej ofenzívnej snahe o dobytie Anglicka. Aj 
napriek vel'kej povojnovej iniciatíve za opätovné vybudovanie tejto legendárnej sály sa vtedajšia vláda rozhodla, že prakticky totálne zdemolovanú sálu nebude rekonštruovat'. Podobný osud postretol viacero významných stavieb, od koncertných sál až po katedrály. Rozsah tejto deštrukcie prinútil svetové spoločenstvo rozpracovat' koncept ochrany a zachovania svetového kultúrneho dedičstva. V roku 1946 vznikla v Paríži Organizácia Spojených národov pre vzdelávanie, vedu a kultúru (United Nations Educational, Scientific and Cultural Organization - UNESCO). Následne v roku 1954 sa problematika ochrany kultúrneho dedičstva a hodnôt v čase ozbrojeného konfliktu riešila v rámci Haagskej konvencie. ${ }^{5}$ O dekádu neskôr v roku 1964 bola prijatá Benátska charta o ochrane a obnove pamiatok a sídiel. Stalo sa tak na 2. Medzinárodnom kongrese architektov a technikov historických pamiatok. Táto charta bližšie definuje kultúrne dedičstvo a zdôrazňuje potrebu jeho zachovania pre budúce generácie. ${ }^{6}$ K d’alším chartám a konvenciám zaoberajúcim sa tematikou kultúrneho dedičstva patrí Charta Európskej rady, Dohovor na ochranu svetového kultúrneho a prírodného dedičstva (konvencia prijatá na generálnej konferencii UNESCO v roku 1972), ${ }^{8}$ Európska charta architektonického dedičstva (prijatá v Amsterdame v roku 1975) ${ }^{9}$ a Dohovor o ochrane architektonického dedičstva Európy (konvencia prijatá v Granade v roku 1985). ${ }^{10}$ Budovy historického významu sú neoddelitel’nou súčastou kultúrneho dedičstva každej krajiny. V modernej spoločnosti by snaha o ich ochranu a uchovanie na národnej úrovni mala byt' už samozrejmostou. Zachovanie kultúrneho dedičstva bolo spočiatku úzko späté prevažne s objektmi hmotného charakteru. Kultúrne dedičstvo nehmotného charakteru zohl'adnila až Washingtonská charta v roku 1987, známa ako Charta pre ochranu historických miest. ${ }^{11}$ Prvá v histórii klasifikovala nehmotné kultúrne prejavy a tradície ako neoddelitel'nú súčast' svetového kultúrneho dedičstva. Do tejto kategórie patria aj akustické špecifiká architektonických pamiatok. Najdôležitejšími sú hlavne akustické profily divadiel, operných domov, koncertných sál, ale aj sakrálnych stavieb. Revolučný progres v posledných dekádach spôsobil vývoj výpočtových technológií a priestorovej akustiky. Konkrétne ide o efektívnost' spôsobu získavania a archivácie precízneho akustického profilu pamiatok. Vd’aka najmodernejším metódam merania a modelovania akustiky pomocou impulznej odozvy je možné, aby sa akustický profil významných architektonických pamiatok zachoval pre budúce generácie aj v prípade totálneho zničenia samotnej budovy. Pridanou hodnotou je aj fakt, že akustický profil má digitálnu formu. Znižujú sa tak náklady aj riziká spojené s jeho archiváciou. Akustický výskum zároveň prispieva k poznaniu a pochopeniu týchto pamiatok. Dopĺña výskumné úsilie ostatných vedných disciplín, s ktorými spoločne vytvárajú komplexnú databázu.

\section{Metodika merania akustických vlastností priestoru}

Pri vol'be adekvátnej metodiky pre náš výskum sme vychádzali z požiadaviek, ktoré sú stanovené normami STN EN ISO 3382-1 a STN EN 60268-16. Pôvodne oba objekty, ktoré sa stali predmetom nášho skúmania, slúžili výhradne sakrálnym účelom. Ich exteriérové a interiérové usporiadanie vychádza primárne z potreby naplnenia požiadaviek s tým súvisiacich. Synagóga v Prešove už v súčasnosti slúži hlavne na organizovanie podujatí hudobného charakteru, vzhladom na jej architektonické dispozície a proporcie sú to prevažne komorné koncerty. Podobne je na tom aj d’alší skúmaný objekt, Synagóga 
v Košiciach. Nakol'ko v nej stále prebiehajú rekonštrukčné práce a rôzne výskumné aktivity, zatial' nie je otvorená pre verejnost'. Už v tejto fáze je však jasná jej nová funkcia. Po otvorení má splńat' úlohu koncertnej sály, konat’ by sa tu mali aj vernisáže a rôzne podujatia typu prednášok a diskusií. Obe, Synagógu v Prešove ako aj tú košickú, môžeme z hudobného hladiska považovat' za priestory komorného charakteru. Vel'kou výhodou skúmaných objektov sú ich symetrické architektonické dispozície na pozdĺžnej osi, čo umožňuje zjednodušit’ akustické merania iba na jednu polovicu priestoru. Faktom je, že ani jeden z objektov nebol doposial' podrobený skúmaniu akustických vlastností. Je dôležité podotknút', že v rámci výskumu sme sa pokúsili realizovat’ čo najviac typov meraní a pokryt’ tak širšie spektrum objektívnych parametrov. Namerané hodnoty môžu poslúžit' pri vyhodnocovaní kvality akustiky z hladiska využitia priestorov na koncertné účely, ale aj ako sakrálne budovy. Z týchto dôvodov sme sa rozhodli pre metodiku merania, ktorá najefektívnejšie zohladňuje oba aspekty týchto historických priestorov. Nami zvolená metodika je kombináciou odporúčaní pre meranie v sakrálnych priestoroch podla Martellottu ${ }^{12}$ a postupov pre meranie akustiky koncertných sál podla Hidaku, Beraneka a Okanu..$^{13}$ Tieto odporúčania a postupy boli do praxe zavedené s ciel'om unifikovat' proces merania a minimalizovat' rozdiely vo výstupoch jednotlivých výskumných projektov. Vd’aka tomu je možné vzájomne porovnávat' kvalitu akustických vlastností rôznych významných stavieb v globálnom rozsahu.

Dôraz sme kládli hlavne na tri základné faktory ovplyvňujúce meranie:

- vol'ba pozícií zdrojov zvuku,

- vol'ba rozmiestnenia meracích pozícií,

- vol'ba technického vybavenia a metodika.

\section{Pozície zdroja zvuku}

Vol'ba pozície zdroja zvuku v maximálnej možnej miere zodpovedá prirodzenému zdroju zvuku v priestore. V prípade koncertných sál by sa zdroj zvuku mal logicky nachádzat' na pódiu a prípadne na dvoch pozíciách. Dve pozície sú vhodné na simuláciu širších prirodzených zdrojov zvuku (orchester). Hlavný zdroj zvuku by mal byt' umiestnený v strede pódia v súlade s pozdĺžnou osou miestnosti a jeho pozícia by mala ostat konštantná. Súčasne slúži aj ako referenčný zdroj. Mala by byt' dodržaná minimálna vzdialenost' 1,5 m od okolitých pevných bariér a objektov. Tieto pravidlá týkajúce sa hlavného zdroja zvuku platia rovnako aj pre meranie v sakrálnych priestoroch. Ak nie je možné túto podmienku dodržat’ kvôli pevnej prekážke, v sakrálnych priestoroch ňou môže byt' napríklad oltár, tak potom je dovolené posunút zdroj zvuku o $1 \mathrm{~m}$ od stredovej osi. Sakrálne priestory môžu mat’ aj viac pozícií zdroja zvuku a vo vel'kej miere záleží na individuálnych podmienkach. Dôležité je, aby sa pozície zdroja nachádzali na všetkých miestach, odkial' sa prednáša liturgický text (pred oltárom, kazatelňa a ambos). V prípade synagóg je hlavná pozícia zdroja na sakrálne účely umiestnená v priestore, kde sa nachádza bima. Špeciálny prístup si vyžaduje prípad, ked'je súčastou priestoru väčšia kupola. Ak sa hlavný zdroj zvuku nachádza mimo jej pôdorysu, vtedy sa vyžaduje použitie dodatočného zdroja. Ten má byt' umiestnený na osi symetrie kupoly $v$ nasledovne vymedzenom priestore: minimálne $2 \mathrm{~m}$ od stredu a minimálne $2 \mathrm{~m}$ od okraja geometrickej projekcie kupoly na podlahe. Pre všetky pozície zdroja zvuku platí, že by sa mali nachádzat' vo výške 1,5 m od podlahy. 


\section{Rozmiestnenie meracích pozícií}

Problematika rozmiestnenia meracích pozícií je v porovnaní s pozíciami zdroja zvuku komplikovanejšia. Hlavné limitácie spočívajú v časových, personálnych, dispozičných a technologických možnostiach. Finálne rozhodnutie je potom väčšinou vec kompromisu medzi dvoma rovinami. Prvou je snaha o dosiahnutie čo najdetailnejšieho obrazu o jednotlivých meraných parametroch, to prirodzene zvádza k použitiu čo najväčšieho počtu pozícií zdroja aj meracích pozícií. Druhou vyvažujúcou rovinou je časové obmedzenie, na ktoré je meraný priestor k dispozícii. Počet výskumných pracovníkov je tiež dôležitý, nakol'ko treba presúvat' jednotlivé pozície a vykonávat' dalšie aktivity, spojené s ukladaním nameraných dát a podobne. To všetko má v konečnom dôsledku vplyv na trvanie merania. Racionálny prístup hladania optimálneho kompromisu medzi týmito rovinami je teda nevyhnutný. Významnú úlohu zohrávajú aj architektonické dispozície priestoru. Čím väčší je objem a rozloha priestoru, tým viac meracích pozícií bude potrebných. Takisto je treba zohladnit balkóny a terasovité auditórium sál. Pri sakrálnych priestoroch zohráva rolu aj prípadná asymetria meraného priestoru a jeho vnútorné členenie. Ďalším faktorom je rozmiestnenie meracích pozícií aj na miesta na státie, v prípade väčšej účasti poslucháčov.

Norma ISO 3382 vyžaduje, aby membrány meracích mikrofónov boli vo výške 1,2 m, čo zodpovedá pozícii, v akej sa nachádzajú uši sediaceho človeka. Mikrofóny na meracích pozíciách by zároveň mali mat’ odstup minimálne $1 \mathrm{~m}$ od pevných bariér a $2 \mathrm{~m}$ od seba navzájom. Pri sálach vel'kých objemov a rozmerov je nutné tieto vzdialenosti prispôsobit', inak by dochádzalo ku skresleniu hodnôt niektorých parametrov. Ani jeden z nami skúmaných objektov však do tejto kategórie nespadá, preto sa problematike prepočtu optimálnych vzdialenosti nevenujeme.

Vzhladom na zohl'adnenie vyššie uvedených faktorov a normatívnych nárokov sa počet meracích pozícií a ich lokácia pri jednotlivých objektoch primerane odlišuje. Klúčové podmienky sa nám podarilo dodržat', zvolené meracie pozície svojím umiestnením a počtom zodpovedajú možnostiam a potrebám meraní v daných priestoroch.

\section{Technické vybavenie a postup merania}

Merania akustických vlastností synagóg v Prešove a Košiciach, ktoré sa súčasne primárne využívajú ako koncertné sály, boli realizované s identickým technickým vybavením:

- Roland Quad Capture USB 2.0 - zvuková karta (AD/DA),

- Ntek OMNI - všesmerový zdroj zvuku,

- Prodipe Pro 8 - dvojpásmový aktívny smerový reproduktor,

- Audix TM1 Plus - kalibrovaný merací mikrofón s gulovou smerovou charakteristikou,

- Behringer ECM8000 - merací mikrofón s gulovou smerovou charakteristikou,

- Soundman John - umelá meracia hlava s anatomicky presnými ušnicami,

- Soundman OKM II - set kalibrovaných mikrofónov pre binaurálne meranie,

- Artalabs ARTA - softvér na meranie a záznam akustických dát,

- AudioEase Altiverb 7 - konvolučný dozvukový softvér.

Zostava technického vybavenia je v súlade s požiadavkami normy STN EN ISO 3382. Pred každým meraním je dôležité overit plnú funkčnost' meracieho aparátu. Výhodou je plánovanie harmonogramu potrebných úkonov a informácie o okolí meraného objektu, nakol'ko výrazný hluk v pozadí (stavebné práce, železničná trat', rušná ulica a iné) by mo- 
hol skreslit’ namerané údaje, prípadne znemožnit’ celý merací proces. V našom prípade sa oba objekty nachádzali v relatívne tichom prostredí. Prvým úkonom bolo zmeranie vnútorných rozmerov sál a fotodokumentácia na účely dodatočného vytvorenia pôdorysu v softvéri AutoCAD. Na základe rozmerov sály sme určili počet a umiestnenie meracích pozícií (M/P). Ak bol súčastou interiéru balkón alebo druhé podlažie tvorené galériou, tak aj tam sme umiestnili jednu až dve meracie pozície. Lokáciu zdroja zvuku (Z) sme určovali podla toho, kde sa bežne v danom priestore nachádzajú vystupujúci interpreti. V prípade merania parametrov súvisiacich so šírením l'udskej reči sme pozície zdroja zvuku umiestňovali tam, kde by sa bežne nachádzal rečník prednášajúci liturgický text. Z praktického hladiska je efektívne vyznačit’ všetky pozície na podlahe. Presúvanie meracích mikrofónov a zdroja zvuku medzi jednotlivými pozíciami je tak ovela rýchlejšie. Špecializovaný softvér na akustické merania ARTA sme použili pre nastavenie vstupnej citlivosti meracej zostavy, generovanie testovacích signálov a záznam impulznej odozvy sály. Pred samotným meraním sme nastavili optimálnu hladinu citlivosti mikrofónu (-10dB). Pre parametre $T_{20^{\prime}} T_{30^{\prime}} E D T, C_{80}$ a $B R$ sme použili spojito prelad'ovaný sínusový tón. Parametre IACC a STI sme merali pomocou širokospektrálneho periodického šumu. Ako prvý sme použili kalibrovaný merací mikrofón s gulovou charakteristikou. Testovací signál, generovaný všesmerovým zdrojom zvuku, bol spojito prelad’ovaný sínusový tón. Meranie sme začínali so zdrojom zvuku v prvej pozícii (Z1) a meracím mikrofónom, rovnako v prvej meracej pozícii (M1/P1). Na každej meracej pozícii sme vykonali sériu troch meraní, z ktorých softvér vygeneroval priemernú hodnotu pre danú pozíciu. Po ukončení meraní mikrofónom sme zachovali zdroj v prvej pozícii (Z1). Nasledovalo meranie binaurálnou technikou s použitím umelej hlavy a setu meracích mikrofónov, ktoré sme vsadili do ušníc umelej hlavy. Testovacím signálom pre túto techniku bol širokospektrálny periodický šum. Opät’ prebehli priemerované merania na každej pozícii, s rovnakým postupom ako pri meraní mikrofónom s gul'ovou charakteristikou.

Po ukončení týchto dvoch typov meraní so zdrojom zvuku v prvej pozícii (Z1) bol zdroj zvuku premiestnený do druhej pozície (Z2). Meracie pozície ostali zachované a opakovane na všetkých prebehli dva vyššie uvedené typy meraní. Najprv monaurálne merania s kalibrovaným mikrofónom a po nich binaurálne merania s umelou hlavou. Postupnost' bola rovnaká, zmenila sa teda len pozícia zdroja zvuku, z prvej (Z1) na druhú vybratú pozíciu (Z2). V priestoroch, kde to bolo potrebné, sme realizovali aj meranie kvality prenosu reči. Na tento typ merania sme využili dvojpásmový smerový reproduktor, ktorý je svojím vyžarovaním na tento účel vhodnejší.

Posledným krokom výskumu bolo vytvorenie akustického profilu pre použitie v konvolučnom dozvukovom softvéri Altiverb. Postupovali sme podla odporúčaní výrobcu uvedeného softvéru. Použili sme všesmerový zdroj zvuku, ktorý generoval spojito prelad'ovaný sínusový tón po dobu 30 s (+16 s potrebných pre dozvuk v priestore). Ten sa nachádzal v prvej pozícii (Z1). Celkovo sme použili dve dvojice meracích pozícií. Prvá dvojica mikrofónov sa nachádzala vo vzdialenosti 4 m od zdroja zvuku, od pozdlžnej osi sály boli vysunuté každý o $2 \mathrm{~m}$ do oboch strán (predný stereo pár). Druhá dvojica bola umiestnená smerom dozadu od prvej o d’alšie $4 \mathrm{~m}$, s rovnakým odstupom od pozdĺžnej osi sály (zadný stereo pár). Zaznamenané dáta impulznej odozvy sme potom konvertovali prostredníctvom softvéru Altiverb IR-Preprocessor. Takto vytvorený akustický profil sály je možné použivat' pre potreby zvukovej postprodukcie alebo archivovat’ ako formu nehmotného kultúrneho dedičstva. 
Spracovanie dát nameraných softvérom ARTA je pomerne komplikovaný a zdíhavý proces, vyžaduje sa pri ňom zvýšená pozornost'. Každá kombinácia pozície zdroja a meracej pozície predstavuje jeden súbor dát, ktorý je možné zobrazit’ v hodnotách pre oktávové alebo tretinooktávové pásma. Dáta pre jednotlivé parametre sme museli manuálne kopírovat’ do softvéru Microsoft Excel. V ňom sme ich dopĺňali do vopred pripravených tabuliek, každý parameter mal vlastnú tabul'ku, kde horizontálna os predstavovala frekvenčné pásma a vertikálna os predstavovala jednotlivé meracie pozície. Následne sme kalkulovali pre každé frekvenčné pásmo daného parametra priemernú hodnotu, priemerovaním konkrétnych hodnôt jednotlivých meracích pozícií. Z takto získaných priemerných hodnôt sme vyhotovovali grafy s krivkami priebehu jednotlivých parametrov v časovej alebo energetickej doméne.

\section{Transformácia sakrálnych objektov na koncertné sály}

Globálne existuje široká škála objektov, ktoré sa využívajú ako koncertné sály. Boli postavené v rôznych historických obdobiach, architektonických štýloch, dispozíciách a kapacitách. Ich primárnym a jediným určením v čase, ked' boli postavené, nemuselo byt' nevyhnutne využitie na koncertné účely. S vel'kou pravdepodobnostou bola vel'ká čast' týchto priestorov navrhovaná a realizovaná s odlišným zameraním. Je nutné podotknút', že takýto vývoj nie je z historického hladiska výnimočný, ale patrí k prirodzenej evolúcii týchto objektov. Z histórie poznáme vela prípadov, ked'boli koncertné sály vybudované v priestoroch s pôvodne odlišným zameraním, alebo sa koncertné sály využívali na alternatívne účely, ak si to vyžadovala situácia. Jedným z najstarších príkladov je využívanie odeonov pre potreby armády v starovekom Grécku. V začiatkoch budovania operných sál sa na tento účel využívali nevyužívané objekty s iným primárnym účelom. Rovnako vzniklo legendárne divadlo Olimpico, ktoré bolo vsadené do priestorov bývalej vojenskej pevnosti Castello del Territorio. ${ }^{14}$ Priestory divadiel a koncertných sál sa často využívali multifunkčne. V súčasnej dobe je to jedna zo základných požiadaviek na tento typ stavieb, ktorá sa zohladňuje a spracováva už v počiatočnej fáze architektonického návrhu. Takéto priestory sa potom adekvátne prispôsobujú plnohodnotnému uspokojeniu sekundárnych potrieb komunity, ktorej slúžia. Politické rokovania, kongresy, odovzdávanie cien a vyznamenaní, nahrávky väčších hudobných telies, vernisáže, plesy, ale aj mnohé d’alšie spoločenské podujatia sa organizujú v moderných multifunkčných koncertných sálach dneška. Zaujímavým príkladom je londýnske nahrávacie štúdio The Church Studios umiestnené v bývalom kostole. Na popularite naberajú aj vystúpenia svetových dídžejov a interpretov elektronickej hudby, organizované francúzskym dramaturgickým zoskupením Cercle, ktoré sa občas konajú aj v priestoroch rôznych historicky významných objektov. Takéto podujatia t’ažia z pridanej hodnoty týchto objektov po stránke akustickej aj estetickej.

Na území súčasného Slovenska sa nachádza mnoho objektov, ktoré boli z rôznych dôvodov pretransformované na koncertné sály, alebo bola ich funkcionalita o tento účel rozšírená. Smutným faktom však je, že mnohé historické koncertné priestory, ktoré sú súčastou väčších komplexov (kaštiele, zámky, župné domy a iné), sú v dezolátnom stave, alebo už nezvratne spustli. Dôvodom je absencia adekvátnej starostlivosti štátu o kultúrne pamiatky v posledných dekádach. Reprofilizácia využitel'nosti 
historického objektu na multifunkčnú koncertnú sálu môže byt’ neraz posledným možným spôsobom záchrany a zachovania týchto kultúrnych pamiatok. Návštevníci tak môžu nepriamou cestou spoznávat' ich historický pôvod a význam, v neposlednom rade prispievajú k financovaniu chodu a opráv týchto objektov, či už vo forme platby vstupného (koncert, vernisáž a iné) alebo prostredníctvom dobrovol'ného príspevku.

Medzi najvýraznejšie prípady transformácie tohto druhu na Slovensku v súčasnosti patria židovské synagógy. Kedže sa zaoberáme akustickými vlastnost’ami koncertných sál, ktoré boli vybudované a pôvodne slúžili ako synagógy v mestách Prešov a Košice, tak je dôležité predstavit’ spoločenský a kultúrny kontext, ktorý viedol k ich vzniku a ovplyvnil ich architektúru. Spolu s mestom Bardejov majú Košice a Prešov na svojom území vysoký počet židovských pamiatok zachovaných v rámci chránených urbanistických zón. V tomto smere ide o mestá s medzinárodným významom.

Život židovských komunít vo všeobecnosti nebol jednoduchý už od čias ich príchodu na územie dnešného Slovenska. Jednotlivé komunity sa navzájom odlišovali na základe politických podmienok, v akých sa vyvíjali, čo malo značný vplyv aj na architektúru synagóg a ostatných židovských stavieb. Vývoj v týchto mestách tak nie je možné generalizovat' aj napriek ich relatívnej vzájomnej blízkosti. Vnútorné spory viedli k odštepovaniu nábožensko-ideologických frakcií, z ktorých vznikali nezávislé kongregácie na území každého z miest. Oficiálne uznané židovské kongregácie boli ortodoxné, neologické, status quo ante a chasidské. Odlišovali sa aj mierou akulturácie, liturgiou a preferenciami v architektúre, ktorá tieto rozdiely umocňovala. Prešov aj Košice boli koncom 18. storočia prosperujúce centrá obchodu so stabilnými cechmi, ktoré si strážili svoje výsady a prostredníctvom byrokratických nástrojov zamedzili židovskej konkurencii usadit' sa v meste. Vo vel'kej miere sa na tomto procese podiel'ali aj inštitúcie a predstavitelia katolíckej cirkvi. Židovské komunity boli nútené usadit’ sa na perifériách miest, na pozemkoch šlachty, ktorá profitovala z daní za užívanie pôdy a zároveň obchodníci židovského pôvodu pôsobili ako distribútori pol'nohospodárskych komodít. ${ }^{15}$ Prvé modlitebné domy v mestách boli zriad’ované vel'mi skromne a niektoré $z$ nich dokonca $v$ tajnosti, aby o nich nevedeli dobové miestne autority. Z architektonického hladiska nespĺňali špecifiká synagóg a vznikali v už existujúcich budovách, ktoré si židovskí obchodníci kupovali, aby v nich mohli príležitostne prespávat'. V dedinách ned’aleko miest, kde sa pôvodne židovské komunity usadili, vznikali drevené synagógy, ktorými bol región východného Slovenska známy. Postupným uvol'ňovaním pravidiel $v$ priebehu 19. storočia začali vznikat’ v mestách aj oficiálne synagógy. Židovská komunita, podobne ako ostatné minoritné náboženstvá tej doby, bola však stále v znevýhodnenej pozícii. Exteriér synagóg musel splńnat’ estetické normy nariadené cirkvou a úradmi. Až neskoršia občianska a právna emancipácia židovských komunít v druhej polovici 19. storočia priniesla d’alšie uvol'nenie týchto nariadení. Mohla sa tak začat’ transformácia z introvertných synagóg schovaných v bežných komunálnych domoch na synagógy s korektnou architektúrou exteriéru aj interiéru. Jednotlivé komunity budovali väčšinou nové synagógy od základu a ich fasády boli akýmsi prejavom sebavedomia a hrdosti na vlastné náboženské vyznanie. Najčastejšie sa realizovali v románskom, maurskom, byzantskom alebo gotickom architektonickom štýle, ale často sa objavovali aj hybridné kombinácie týchto štýlov. Toto obdobie sa vyznačovalo rapídnym nárastom židovskej urbanizácie a mestá, ktoré sa pred židovskými komunitami uzatvárali, sa postupne stávali pulzujúcimi centrami židovského života. 
Synagóga bola hlavným zhmotnením prítomnosti Židov, ale okrem nej sa budovali rituálne kúpele, školy, kóšer bitúnky, rabináty a d’alšie stavby. Výstavbou boli poverení miestni stavitelia, ktorí hladali inšpiráciu v existujúcich synagógach velkých centier vtedajšej monarchie. Majetnejšie kongregácie si dokonca najímali renomovaných architektov z Viedne, Budapešti alebo Berlína. Nové synagógy zároveň odrážali aj miestnu architektonickú tradíciu, zohl'adňovali charakter stavebného pozemku a urbanisticko-architektonické prostredie, v ktorom mali byt' umiestnené. ${ }^{16}$

\section{Ortodoxné synagógy v Prešove a Košiciach}

Prítomnost' ortodoxnej židovskej komunity v Prešove je najlepšie prezentovaná prostredníctvom unikátne zachovaných náboženských inštitúcií, ktoré sa tu vyvíjali od 80 . rokov 19. storočia. Nachádzajú sa v severozápadnej časti mesta, v tesnej blízkosti vonkajšej časti bývalého opevnenia. V roku 1884 bola založená synagóga v jednoduchej prízemnej budove, ktorá sa po roku 1898 využívala ako študovňa. Pod touto budovou sa kedysi nachádzal prvý prešovský rituálny kúpel'. Neskôr ju rozšírili a po roku 1911 slúžila ako modlitebná sála pre ortodoxnú kongregáciu praktizujúcu liturgiu Aškenázi. Najstaršou budovou je dvojposchodové sídlo rabinátu, ktorého súčastou boli pozostatky bašty historického opevnenia mesta. Pozdížne s ulicou sa tiahne jednoposchodová budova, v ktorej sídlila škola. Na opačnej strane areálu sa nachádzajú kancelárie a bývalý kóšer bitúnok. V roku 1898 bola spoločenstvom slávnostne otvorená nová synagóga, ktorá je predmetom nášho akustického výskumu. $V$ jej tesnej blízkosti sa nachádzal rituálny kúpel', postavený v roku 1904 a zbúraný v povojnovom období. Rýchlo rastúca židovská populácia predstavovala v roku 1921 takmer 1/5 celkovej populácie Prešova. Členovia pôvodnej neologickej kongregácie boli prevažne zo strednej vrstvy meštanov a išlo o komunitu s nízkou pôrodnostou, ktorá navyše nebola príliš atraktívnou volbou pre Židov tradičného vyznania migrujúcich do Prešova. Najviac z nich sa pridávalo k ortodoxnej komunite, ktorá pozostávala z chudobnejších a mnohodetných rodín. Pomer členov neologickej a ortodoxnej komunity bol v 30. rokoch 20. storočia približne 1:3. ${ }^{17}$

Začiatky organizovaného komunálneho života židovskej komunity $v$ Košiciach siahajú do 40. rokov 19. storočia. Prvý obchodník židovského pôvodu sa tu usadil v roku 1841, ale rozsiahle obštrukcie zo strany predstavitel'ov mesta, cechov a cirkvi pokračovali po celé desatročie. Židovská komunita sa usadila v južnej časti mesta a južných predmestiach, kde budovali stavby pre svoje inštitúcie a vd’aka nim tieto lokality nadobudli výrazne židovský charakter. Vznikajúca židovská komunita zakúpila stodolu na Zvonárskej ulici, ktorá kopírovala líniu bývalého opevnenia mesta. Súčastou bol aj rozlahlejší pozemok, na ktorom postupne vzniklo centrum židovského spoločenského života v Košiciach, slúžiace komunitným potrebám až dodnes. Stodola bola upravená, aby mohla slúžit ako synagóga a na južnej strane k nej bol pristavaný rituálny kúpel', ktorý je jedným z dvoch zachovaných v pôvodnom stave na celom území Slovenska. Stará drevená synagóga bola v roku 1899 nahradená novou, stavebnými prácami bol poverený János Balog. V jej okolí sa nachádzali priestory inštitúcií ortodoxnej kongregácie. V roku 1904 bola dokončená jednoposchodová budova na severnej strane areálu, ktorá slúžila ako dodatočné priestory na modlenie a nachádzal sa tu aj kóšer bitúnok. Na východnej strane sa nachádzal objekt slúžiaci pre potreby náboženského 
festivalu Sukot. Populácia židovskej komunity výrazne narastala a v roku 1930 žilo v Košiciach vyše 11000 občanov hlásiacich sa $k$ židovskej viere. ${ }^{18}$

Antisemitské procesy koncom 30. rokov 20. storočia vyplývajúce z nových ideológií šíriacich sa v európskom politickom priestore dramaticky zmenili hospodárske, spoločenské a politické postavenie židovských komunít v mnohých krajinách. Príkladom je Arizačný proces spustený 1. 2. 1940, ktorý postupne pripravil židovské komunity o všetok ich majetok a podniky. Toto temné obdobie vyvrcholilo počas druhej svetovej vojny deportáciami do vyhladzovacích pracovných táborov mimo územia Slovenska. Povojnové obdobie sa nieslo v rovnako nepriaznivej atmosfére. Dôkazom sú tragické udalosti z Topol'čian a obce Kolbasov. Začiatkom roka 1948 žilo na Slovensku v 41 obnovených obciach zhruba 30000 Židov, ktorí prežili holokaust. Ked' však bol v tom istom roku nastolený komunistický režim, tak väčšina slovenských Židov emigrovala do Izraela, Spojených štátov amerických, Kanady, Austrálie a iných krajín v zahraničí. Komunistický režim svojím prístupom k židovskej komunite zmaril jej úsilie o obnovu komunitného života a aktivít. Štátna bezpečnost’ aktívne sledovala, zastrašovala a zhromažd’ovala informácie o židovských občanoch. Takmer všetci, ktorí na území Slovenska ostali, skrývali svoje náboženstvo, vytvárali si alternatívne životy a postupne splynuli s majoritnou spoločnost’ou. Niektoré synagógy na Slovensku boli zničené v prvej polovici 20. storočia. Ostatné, až na pár výnimiek, v časoch komunistického režimu chátrali nevyužité, alebo sa využívali na alternatívne účely. $V$ súčasnosti majú synagógy rôznych vlastníkov a správcov. Najčastejšou formou ich alternatívneho využitia sú muzeálne účely, spomienkové výstavy, ale aj vernisáže, koncerty alebo semináre. Vd’aka svojej jedinečnej architektúre a akustickým vlastnostiam pridávajú týmto podujatiam hodnotu. Zároveň prostredníctvom nich generujú finančné prostriedky, ktoré pomáhajú udržat' ich technický stav a prevádzku. Ostávajú tak zachované pre d’alšie generácie spolu s odkazom na svojich budovatel'ov, ich kultúru, vieru a komunitu.

\section{Akustické vlastnosti koncertnej sály v Prešovskej synagóge}

\section{Charakteristika objektu}

Stavba synagógy bola pôvodne realizovaná košickou stavebnou firmou Kollacsek \& Wirth v rokoch 1897 až 1898. Bola úmyselne orientovaná tak, aby bola dobre viditel'ná pre verejnost'. Projekt bol inšpirovaný synagógou v meste Tokaj. Východná strana, orientovaná do ulice Jarková, vyčnievajúcou častou archy a zaslepenými oknami indikuje nábožensky dôležitú čast' budovy. Fasáda sa skladá z troch častí oddelených piliermi a stredná je lemovaná klenbovými výklenkami. V horizontálnej rovine vyniká ozdobná rímsa a lomený štít strechy. Ide o kombináciu maurského, novorománskeho (Rundbogenstil) a neoklasicistického slohu. Zvyšok exteriéru je v rovnakom slohu s vysokými trojdielnymi oknami. Budova je orientovaná na juhovýchod, v smere na Jeruzalem. Pôvodný hlavný vstup do mužskej sekcie bol na západnej strane. V tomto mieste sa dnes nachádza presklená modlitebňa. V súčasnosti sa nachádza hlavný vchod na osi severnej strany, tvorený je masívnou konzolovou rímsou, ktorú podopierajú piliere s okrasnými hlavicami. Vstup do ženskej sekcie sa nachádza v severozápadnom rohu budovy. Zariadenie interiéru rešpektuje všetky ortodoxné nároky a je v zachovalom pôvodnom stave. Mužská a ženská čast’ 
sú separované, v strede sály sa nachádza bima, zachovali sa pôvodné lavice na sedenie a pôsobivá výzdoba interiéru má viacero orientalizujúcich črt. Autorom nástenných malieb je Andrej Grazl. Bohato dekorovaná archa (Aron ha-kodeš), kde je uložená Tóra, je dielom košického sochára Andreja Bacsóa. Interiér je tvorený trojlod’ovou sálou, druhé podlažie tvorí galéria podopretá ocel'ovými piliermi. Dominuje tu maurský štýl a hlavice stĺpov zdobené ornamentálnou polychrómiou. Exteriér budovy prešiel rekonštrukciou v 90. rokoch minulého storočia. V súčasnosti plní aj úlohu múzea. Hlavnú čast’ expozície tvorí Bárkányho kolekcia pamätihodností, ktorá je špeciálnou výstavou Múzea židovskej kultúry pod záštitou Slovenského národného múzea. Jeden z exponátov vypovedá o žiadosti kongresu Spojených štátov amerických o možnost' presunu prešovskej synagógy do USA. Mala sa tak stat' symbolom historického odkazu židovstva na Slovensku. Túto iniciatívu z roku 1989 spustil hlavný predstavitel'židovskej obce v Missouri A. Gephardt. ${ }^{19}$

Súčasne sa sála tejto synagógy využíva aj na koncertné účely. $Z$ tohto dôvodu bolo v priestore pred svätostánkom vo východnej stene vybudované drevené pódium, na ktorom sa nachádza koncertné krídlo. Výhodou sú priestorové dispozície, ktoré nie sú z akustického hladiska problematické. Tvar kvádra, pomer rozmerov a vnútorné členenie svojím spôsobom dokonca pripomínajú dizajn historických koncertných sál. Sála má nasledovné rozmery:

- dližka-24,4 m,

- šírka-16,0 m,

- max. výška-14,0 m,

- plocha-395 $\mathrm{m}^{2}$,

- objem $-5800 \mathrm{~m}^{3}$.

Koncerty, ktoré sa konajú v sále prešovskej synagógy, sú prevažne komorného charakteru. Ich hudobná dramaturgia je pestrá a prestižni interpreti sú zárukou kvalitného umeleckého zážitku. V roku 2018 sezónu otvoril koncert Thesaurus - židovská hudba 16. - 19. storočia. Koncert bol súčastou celoslovenského turné unikátneho 16-členného medzinárodného komorného súboru, ktorý tvorili členovia slovenského súboru Solamente naturali a ich zahraniční hostia. Hodinový koncert pozostával z hebrejských orientálnych diel z najväčšej kolekcie židovskej hudby. Oživené boli takmer zabudnuté skladby synagogálnej hudby, upravené pre barokový súbor so sekciou autentických exotických nástrojov. Súčastou boli sólové party i zborový spev, ale aj tradičný rytmický sprievod tlieskaním a dupaním. V roku 2019 sa v Prešove konal Festival komornej hudby. V ortodoxnej synagóge sa celkovo konali tri zo štyroch koncertov tejto série. Návštevníci si mohli vypočut virtuózne výkony významných európskych a svetových interpretov. Predstavili sa huslista Milan Pala, klavirista Ladislav Fančovič, sólista Viedenskej štátnej opery Peter Kellner, slovinská flautistka Lana Kuščer a čínska klaviristka Dongni Xie.

\section{Meranie akustiky a vyhodnotenie parametrov}

Priebeh zvolenej metodiky merania je všeobecne zhrnutý vyššie, je však nutné individuálne spresnit špecifické detaily merania v každej sále. V prešovskej synagóge sa zdroj zvuku nachádzal na dvoch pozíciách $(Z 1, Z 2)$, obe na prvom nadzemnom podlaží. Prvá pozícia bola na drevenom pódiu (Obr. 1). Lokácia druhej pozície bola v priestore bimy (Obr. 2), ktorá bola klúčová pri meraní parametra STI. Symetrickost’ sály umožnila rozmiestnenie meracích pozícií iba v lavej polovici priestoru. Celkovo sa na prvom nadzemnom podlaží nachádzalo 12 meracích pozícií (M1 - M12) a v ženskej galérii (Obr. 3), 
o podlažie vyššie, boli umiestnené d’alšie dve meracie pozície (M13, M14). Pozície M1 až M8 sa nachádzali v priestore pod ženskou galériou a pozície M10 a M12 boli vedla bimy tak, aby verne dokresl'ovali akustiku hlavnej časti sály. Posledným meraním bol záznam impulznej odozvy pre vytvorenie akustického profilu na archiváciu. Merania prebiehali v prázdnej sále bez obecenstva.

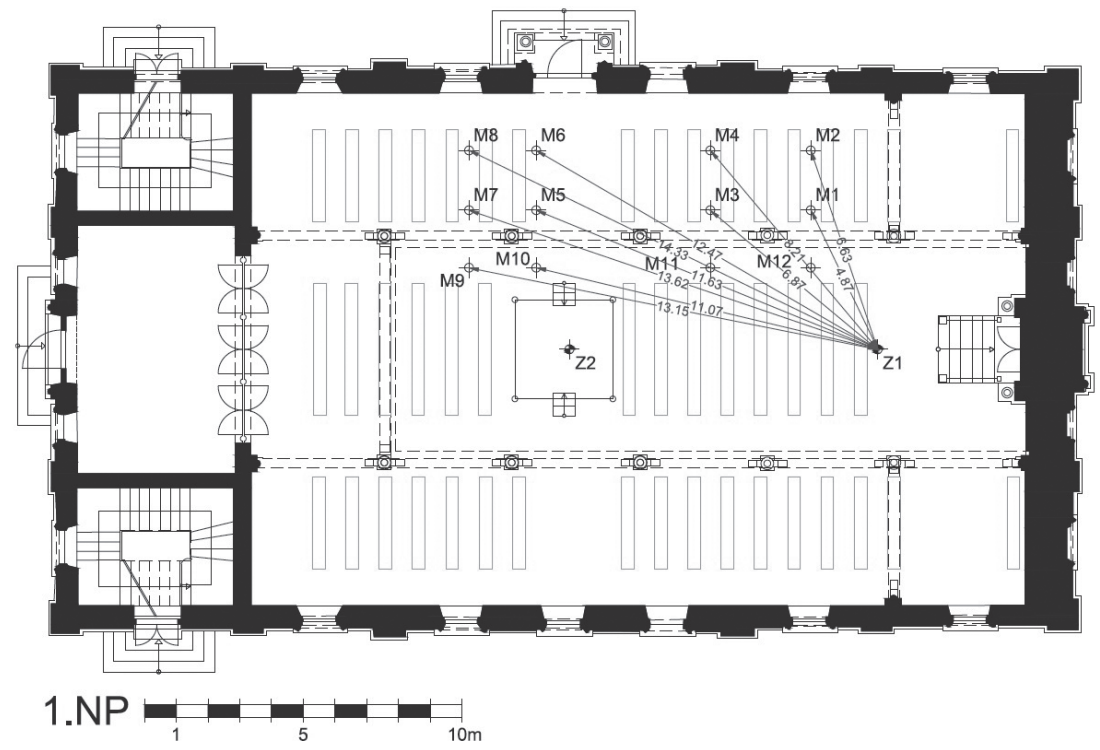

Obr. 1: Pôdorys prvého nadzemného podlažia ortodoxnej synagógy v Prešove $s$ označením zdroja zvuku Z1 a meracích pozícií M1 - M12 $2^{20}$

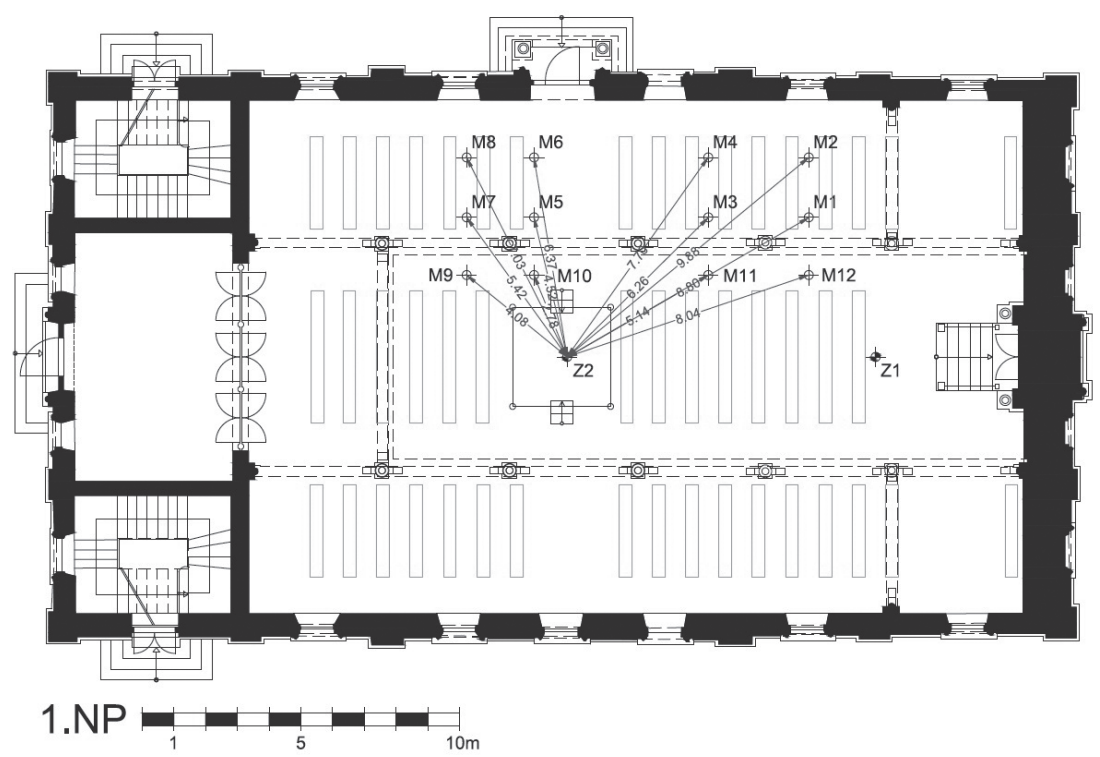

Obr. 2: Pôdorys prvého nadzemného podlažia ortodoxnej synagógy v Prešove $s$ označením zdroja zvuku Z2 a meracích pozícií M1 - M12 ${ }^{21}$ 


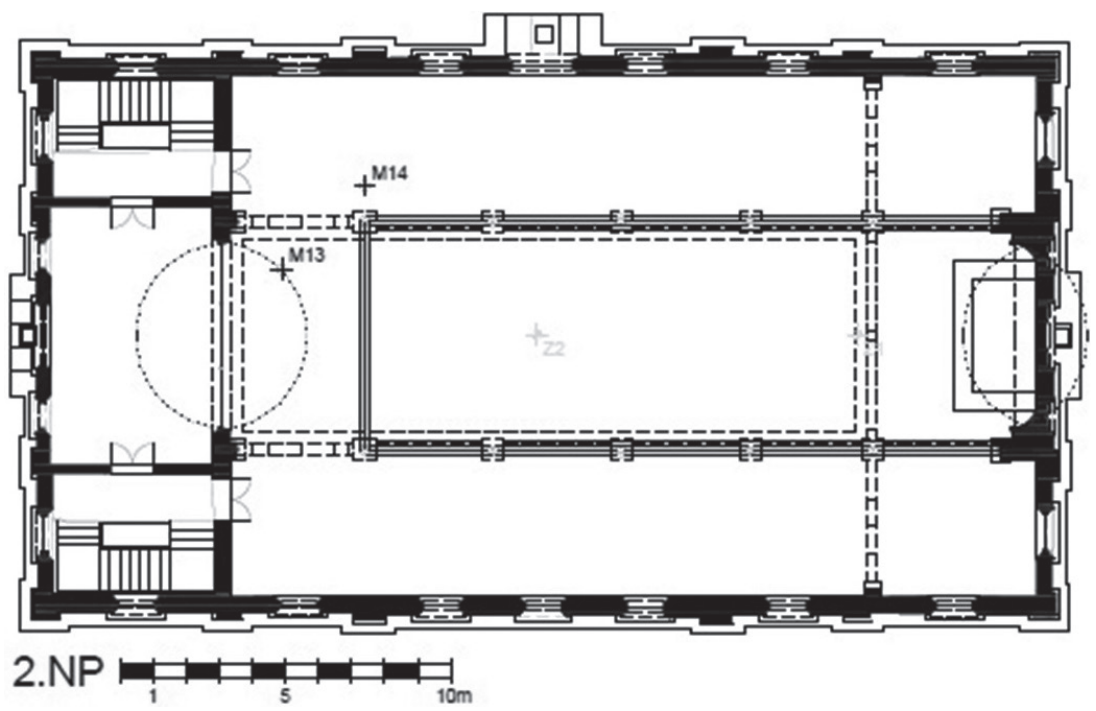

Obr. 3: Pôdorys druhého nadzemného podlažia ortodoxnej synagógy v Prešove (ženská galéria) s označením meracích pozícií M13 a M1422

Hodnoty počiatočného času dozvuku EDT a času dozvuku $T_{30}$ sú vyrovnané naprieč celým frekvenčným spektrom, $v$ žiadnom pásme nepozorujeme rušivé vybudenie alebo prepad (Graf 1 a 2). Maximálna hodnota $\mathrm{T}_{30}$ len o málo presahuje 2,5 s. Vd'aka tomu táto sála umožňuje aj interpretáciu v rýchlejšom tempe, nakol'ko pravdepodobnost' maskovania tónov je nízka. Vplyv na dlžku času dozvuku má aj vnútorné usporiadanie sály, v ktorej sa nachádzajú koberce a pôvodné lavice. Svoju úlohu v tomto smere zohráva aj prítomnosť ženskej galérie, ktorá sa tiahne popri troch stenách, ale aj výrazne členitý strop.

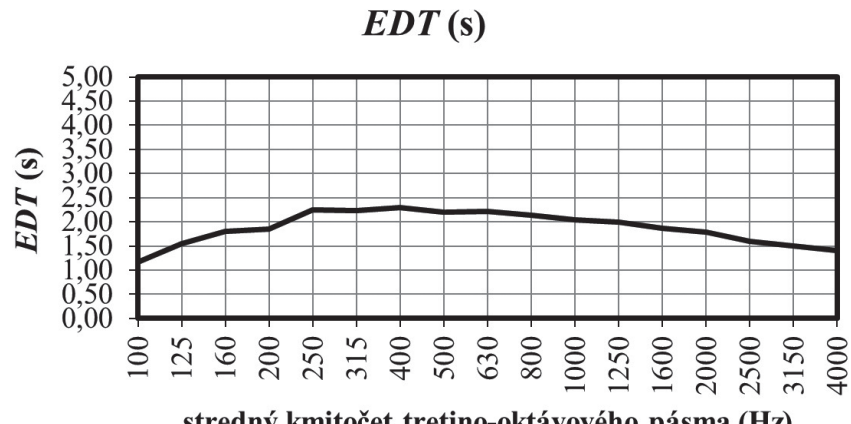

stredný kmitočet tretino-oktávového pásma $(\mathrm{Hz})$

Graf 1: Krivka počiatočného času dozvuku EDT pre Ortodoxnú synagógu v Prešove 


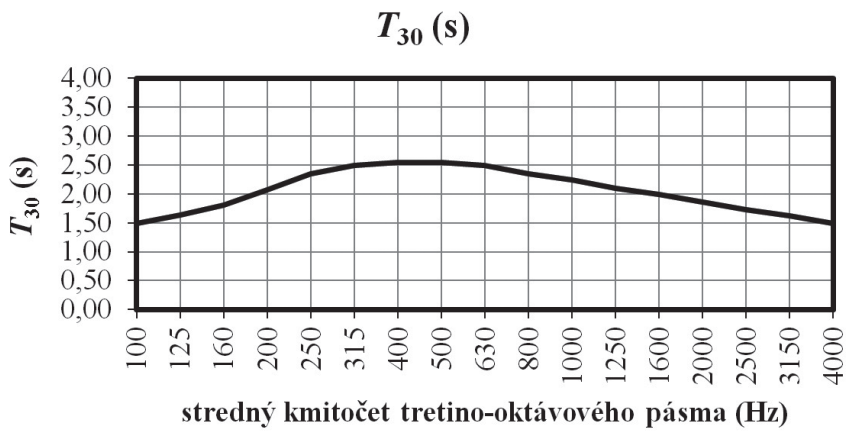

Graf 2: Krivka času dozvuku $T_{30}$ pre Ortodoxnú synagógu v Prešove

Všetky tieto prvky interiéru prispievajú k difúznosti zvukového pola v sále. Tomu zodpovedá aj parameter $C_{80^{\prime}}$ ktorý sa od frekvencie $1000 \mathrm{~Hz}$ pohybuje v kladných hodnotách (Graf 3). Rizikové môže byt’ pásmo 4000 Hz, ale iba pri vel'mi nevhodnom repertoári a v tesnej blízkosti pódia. Ak by išlo o hudbu so silným perkusívnym charakterom a poslucháč by sedel na mieste blízko pódia pod ženskou galériou, mohol by subjektívne vnímat' prichádzajúci zvuk ako príliš ostrý. Zhoršenú distribúciu neskorších odrazov môžu vnímat’ poslucháči v bočných zadných laviciach pod galériou.

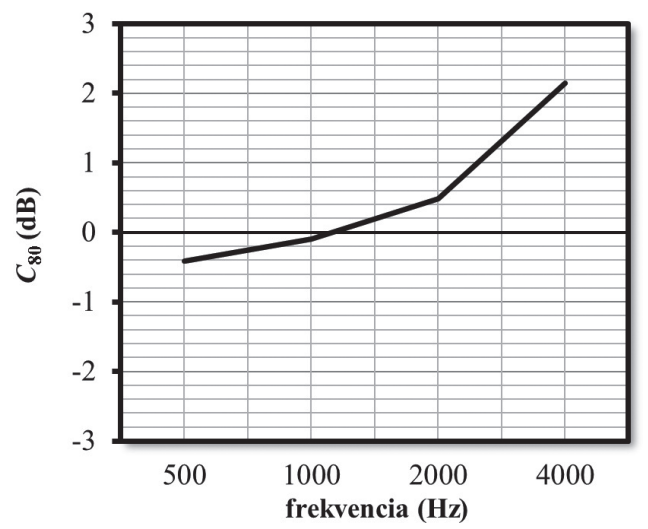

Graf 3: Krivka miery jasnosti $C_{80}$ pre Ortodoxnú synagógu v Prešove

Parameter basového pomeru BR sa svojou hodnotou v tejto sále pohybuje tesne pod minimálnou požadovanou hodnotou (Tabul'ka 1). Vzhl'adom na fakt, že táto sála nebola pôvodne stavaná ako koncertná sála, nie je toto zistenie prekvapením. Prednášaná liturgia tak nebola zahmlievaná prílišným zvýraznením v pásmach nízkych frekvencií. Hudba však môže pôsobit' z hl'adiska subjektívneho vnímania chladnejším dojmom, ked’že parameter BR sa spája so subjektívnym parametrom vrelosti zvuku.

Tabulka 1: Hodnota basového pomeru BR pre Ortodoxnú synagógu v Prešove

\begin{tabular}{|l|l|}
\hline$B R$ & 0,89 \\
\hline
\end{tabular}


Parameter IACC $\mathrm{E}_{3}$ nameranou hodnotou spadá do kategórie excelentného až výnimočného subjektívneho vnímania priestorovosti. Z hudobného hladiska ide o vel'mi priaznivé podmienky na interpretáciu komornej hudby v tejto sále.

Tabul'ka 2: Hodnoty korelačného koeficientu vzájomnej počutel'nosti IACC pre Ortodoxnú synagógu v Prešove

\begin{tabular}{|c|c|c|c|c|c|c|}
\hline stredný kmitočet oktávového pásma $(\mathrm{Hz})$ & 125 & 250 & 500 & 1000 & 2000 & 4000 \\
\hline$I A C C_{E}$ & 0,82 & 0,65 & 0,38 & 0,28 & 0,30 & 0,24 \\
\hline$I A C C_{E 3}=0,32$ & \multicolumn{1}{l}{}
\end{tabular}

Ďalším meraným parametrom bol index prenosu reči STI, ktorý sme sa rozhodli merat’ z dôvodu pôvodného určenia sály na liturgické účely. Dáta tohto parametra a následnú archiváciu tak možno považovat’ za formu ochrany nehmotného kultúrneho dedičstva. Zrozumitel’nost’ reči v sále výrazne závisí od pozície poslucháča voči zdroju zvuku (Graf 4). Zrozumitel'nost' ludskej reči v sále dosahuje z kvantitatívneho hladiska priemernú úroveň.

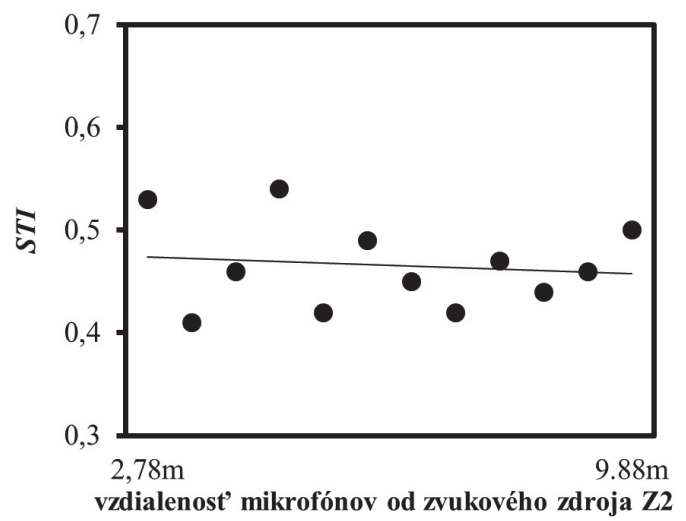

(m)

Graf 4: Graf indexu prenosu reči STI pre Ortodoxnú synagógu v Prešove

Akustické vlastnosti koncertnej sály v synagóge na Zvonárskej ulici v Košiciach

\section{Charakteristika objektu}

V roku 1899 bola postavená nová synagóga na Zvonárskej ulici v Košiciach, ktorá nahradila pôvodnú drevenú. Výstavbou bol poverený lokálny stavitel' János Balogh. Stala sa najdôležitejšou budovou areálu židovskej komunálnej zástavby. Budova má dve poschodia a exteriér je v novorománskom slohu (Rundbogenstil) s miernym vplyvom lokálnej architektúry. V súčasnosti je exteriér už plne zrekonštruovaný. Západná strana je reprezentatívnou častou synagógy a je orientovaná do Zvonárskej ulice. Fasáda má tri časti, ktoré tvoria výrazné poschodové veže. Bočné veže vystupujú smerom do ulice a v spodnej časti 
sa nachádzajú dvere, vo vrchnej sú klenbové okná. Súčast’ou centrálnej veže je hlavný vchod a nad ním sa nachádza vel'ké klenbové okno s ozdobným sklom. Vrchná čast’ veže je zakončená štítom, na ktorom sa nachádzajú kamenné dosky s desiatimi prikázaniami. Ostatné časti exteriéru nie sú také monumentálne, vertikálnym líniám dominujú ozdobné stĺpy a štíhle klenbové okná, horizontálnym zase ozdobná rímsa. Východná strana je opät’ rozdelená na tri sekcie, stredná má vo vrchnej časti vel'ké klenbové okno s dekoratívnou výplňou a je zakončená výrazným štítom. Interiér je vel'kolepo dekorovaný nástennými mal'bami s geometrickými a maurskými motívmi. Na stranách sa nachádza ženská galéria podopieraná liatinovými stĺpmi s ozdobnými hlavicami, podobne ako v prešovskej synagóge. V porovnaní s ňou má menej členitý strop. Sála je momentálne prázdna a prebiehajú v nej rozsiahle rekonštrukčné práce. Z pôvodného vybavenia interiéru sa zachovala iba archa a čast' mobiliáru na západnej stene pri hlavnom vstupe. ${ }^{23}$ Pochôdzna čast' ženskej galérie je v havarijnom stave a momentálne neprístupná. Zavedená je elektroinštalácia a podlahové kúrenie. Konkrétne rozmery sály sú:

- dĺžka - 20,1 m,

- šírka - 13,2 m,

- max. výška - 11,0 m,

- plocha - $266 \mathrm{~m}^{2}$,

- objem - $2600 \mathrm{~m}^{3}$.

Aktuálny stav sály zatial' neumožňuje využívat’ plnohodnotne jej potenciál, ale aj napriek tomu sa tu konajú príležitostné podujatia umeleckého charakteru. V roku 2019 sa tu konal koncert na exotickom hudobnom nástroji Handpan v podaní interpretov Marcel Hutter, Moritz Labschutz a Kodama Hands. Krátko na to sa konal koncert modernej elektronickej hudby v podaní interpretov Saul a Marko Damian. Tieto podujatia svojím charakterom naznačujú progresívne smerovanie tohto unikátneho priestoru. Sála svojím tvarom a rozmermi spĺña predpoklady pre budúce využitie v úlohe koncertnej sály.

\section{Meranie akustiky a vyhodnotenie parametrov}

Priebeh zvolenej metodiky merania je všeobecne zhrnutý vyššie, je však nutné individuálne spresnit’ odlišné detaily merania v každej sále. Prípad košickej synagógy je špecifický z titulu technického stavu jej interiéru. Nami realizované meranie akustických vlastností sály možno v tejto fáze považovat’ za mapovanie aktuálneho stavu. Predpoklad, že sa po dokončení rekonštrukčných prác a zariadení interiéru hodnoty niektorých parametrov zmenia, je pomerne reálny. Ďalšie meranie akustických vlastností v dokončenom priestore sály bude nevyhnutné, čím sa ponúka ideálna príležitost' na porovnanie a vyhodnotenie efektu rekonštrukčných prác na kvalitu akustiky sály.

V budúcnosti sa predpokladá vybudovanie pódia pred priestorom Aron ha-kodeš. Obe pozície zdroja zvuku sme teda umiestnili tak, aby zodpovedali odhadovanej pozícii hudobného telesa. Prvá pozícia zdroja (Z1) sa nachádzala na pozdĺžnej osi sály (Obr. 4) a druhá pozícia zdroja (Z2) bola posunutá vlavo (Obr. 5). Podmienka minimálnej vzdialenosti 1,5 m medzi zdrojmi bola dodržaná. Vzhladom na symetriu sály sme meracie pozície umiestňovali len do lavej polovice priestoru. Celkovo sme zvolili 12 meracích pozícií (M1 - M12), ktoré boli rozmiestnené v štyroch radoch kolmých na pozdĺžnu os sály. Každý rad pozostával z troch meracích pozícií a pozície najbližšie k stene sály sa zároveň nachádzali pod ženskou galériou (Obr. 4 a 5). Do priestoru ženskej galérie sme z bezpečnostných dôvodov meracie pozície neumiestňovali. Merania prebiehali v prázdnej sále bez obecenstva. 


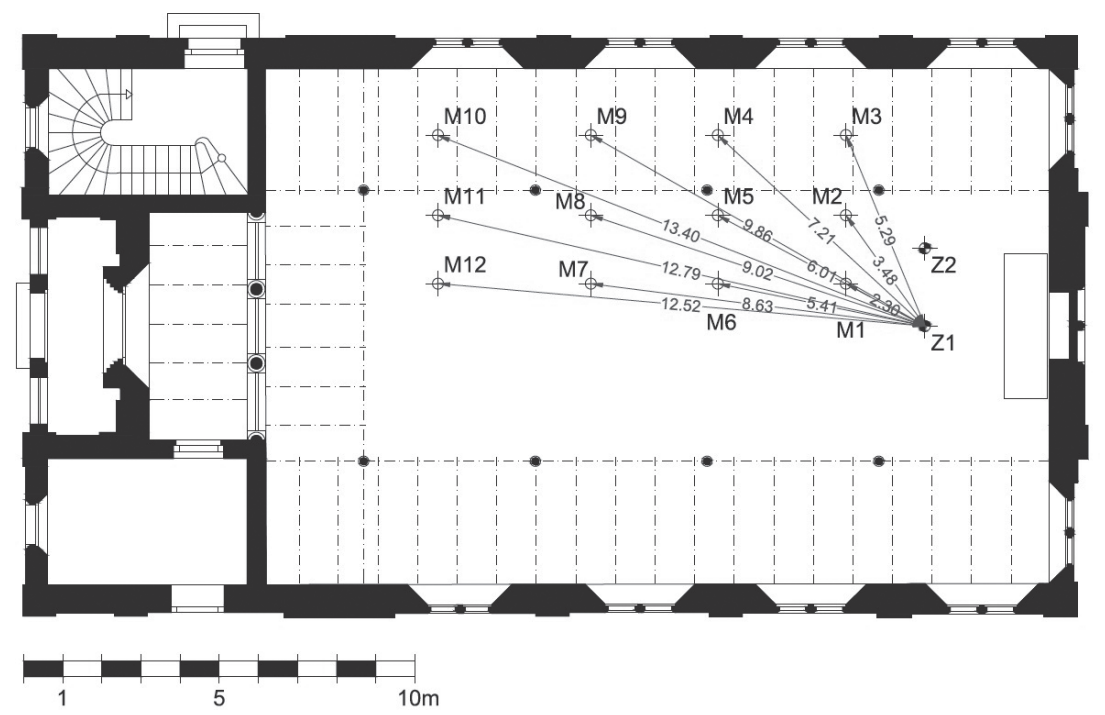

Obr. 4: Pôdorys ortodoxnej synagógy v Košiciach s označením zdroja zvuku Z1 a meracích pozícií M1 - M12 24

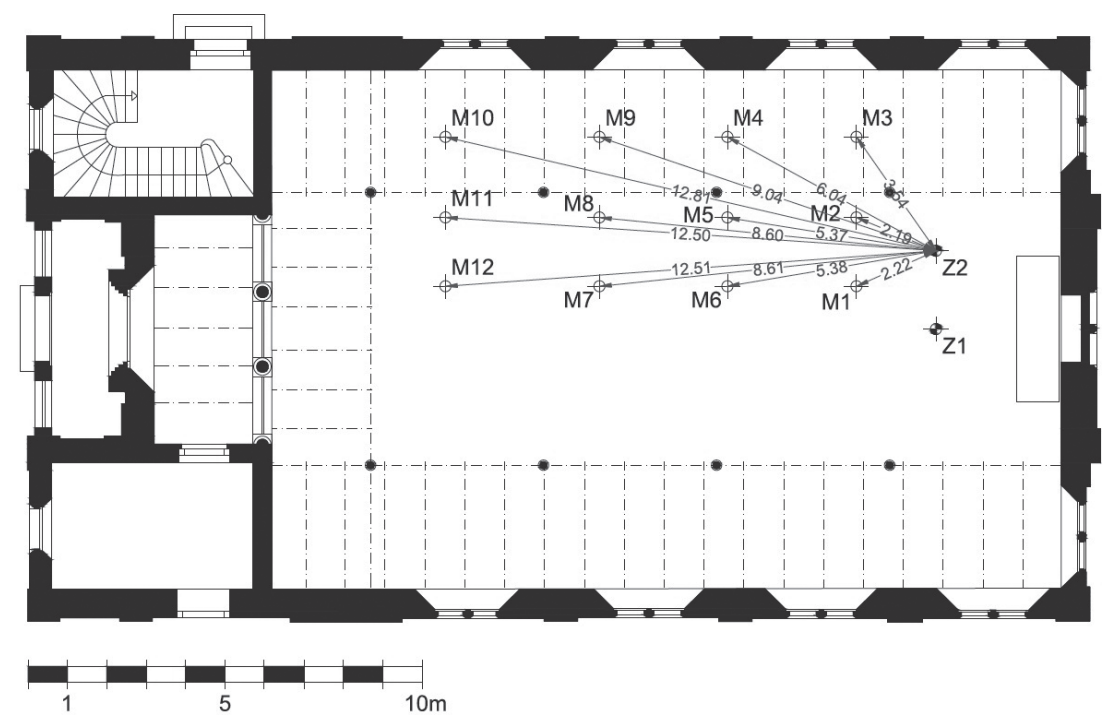

Obr. 5: Pôdorys ortodoxnej synagógy v Košiciach s označením zdroja zvuku Z2 a meracích pozícií M1 - M12 25

Prázdna a menej členitá sála košickej synagógy vykazuje dlhší počiatočný čas dozvuku EDT, ale s menšími odchýlkami medzi jednotlivými pásmami (Graf 5). Z krivky je zrejmé, že vyššie frekvencie doznievajú oproti ostatným rýchlejšie ako v prešovskej sále. Dôvodom je práve menšia členitost' interiéru košickej sály, tým pádom menej neskorých odrazov v pásmach vyšších frekvencií. Podobný priebeh pozorujeme aj pri hodnotách parametra času dozvuku $\mathrm{T}_{30}$ (Graf 6). 


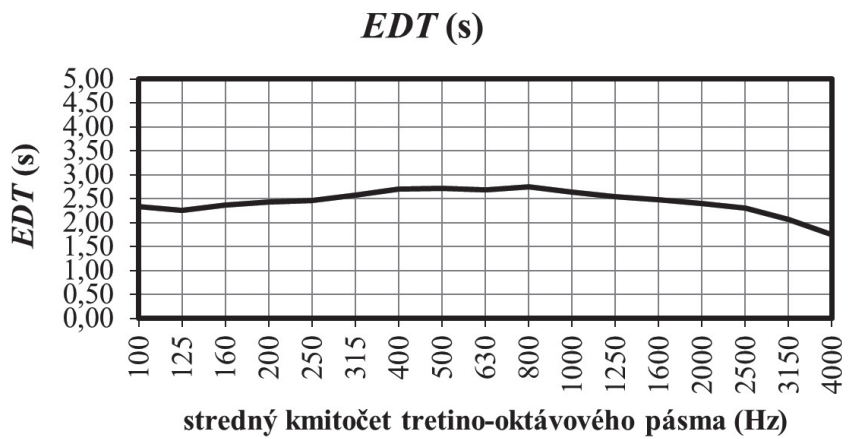

Graf 5: Krivka počiatočného času dozvuku EDT pre Ortodoxnú synagógu v Košiciach

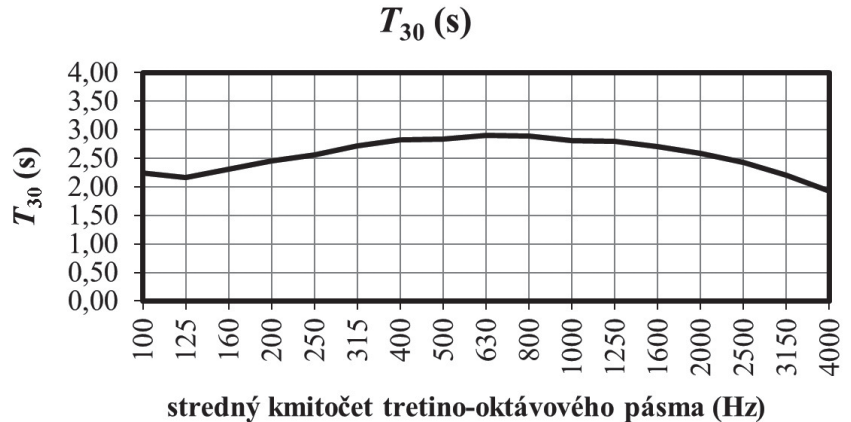

Graf 6: Krivka času dozvuku $T_{30}$ pre Ortodoxnú synagógu v Košiciach

Parameter miery jasnosti $C_{80}$ sa nameranými hodnotami pohybuje v rozsahu -1 až 1 (Graf 7). Na základe toho odporúčame skôr hudbu v pomalšom tempe. Pri rýchlych rytmických úsekoch by totiž mohlo dochádzat’ k vzájomnému maskovaniu po sebe rýchlo nasledujúcich krátkych tónov. Pre takéto sály sú vhodné napríklad vystúpenia speváckych zborov. Bezproblémová by však mala byt' každá hudobná produkcia s tiahlym tempom a rytmikou.

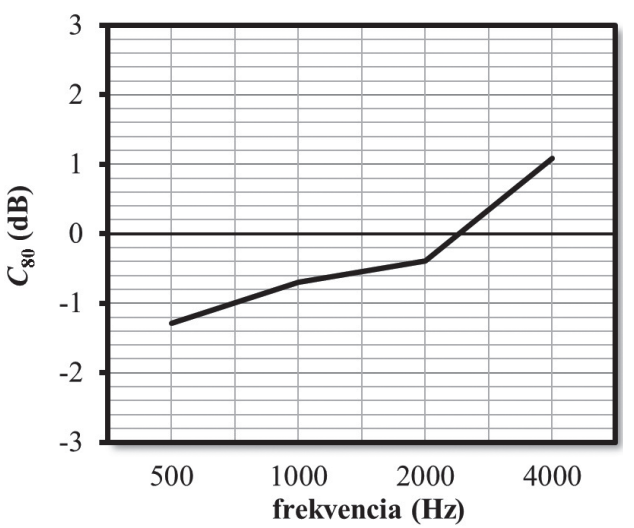

Graf 7: Krivka miery jasnosti $C_{80}$ pre Ortodoxnú synagógu v Košiciach 
Parameter basového pomeru BR v tejto sále dosahuje takmer rovnako nízke hodnoty (Tabul'ka 3), ako sme pozorovali v prešovskej sále. S ohladom na budúci primárny účel sály by bolo vhodné realizovat’ akustické úpravy, ktoré by hodnotu tohto parametra zvýšili, optimálne na úroveň 1,1.

Tabulka 3: Hodnota basového pomeru BR pre Ortodoxnú synagógu v Košiciach

\begin{tabular}{|c|c|}
\hline$B R$ & 0,86 \\
\hline
\end{tabular}

Hodnota IACC $_{\mathrm{E3}}$ (Tabul'ka 4) potvrdzuje vel'mi priaznivé podmienky pre subjektívny vnem priestorovosti.

Tabul'ka 4: Hodnoty korelačného koeficientu vzájomnej počutel'nosti IACC pre Ortodoxnú synagógu v Košiciach

\begin{tabular}{|l|c|c|c|c|c|c|}
\hline stredný kmitočet oktávového pásma $(\mathrm{Hz})$ & 125 & 250 & 500 & 1000 & 2000 & $\mathbf{4 0 0 0}$ \\
\hline$I A C C_{E}$ & 0,85 & 0,60 & 0,28 & 0,25 & 0,29 & 0,25 \\
\hline$I A C C_{E 3}=0,28$ & \multicolumn{1}{l}{}
\end{tabular}

Index prenosu reči STI nebolo možné merat' z autentickej pozície, odkial' sa prednášala liturgia, nakol'ko sa žiadna informácia o nej nezachovala. Meranie sme uskutočnili v orientačnej rovine so zdrojom zvuku v prvej pozícii (Z1). Zrozumitel'nost' reči v tejto sále dosahuje lepšie hodnoty (Graf 8), ako boli namerané v prešovskej sále. Výnimkou sú len prvé tri pozície.

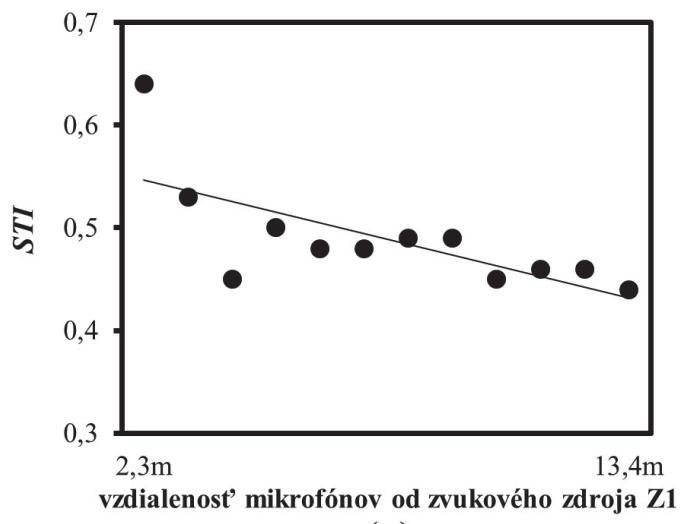

(m)

Graf 8: Graf indexu prenosu reči STI pre Ortodoxnú synagógu v Košiciach

\section{Záver}

Z historického vývoja v európskom priestore vyplýva potreba maximálnej snahy o zachovanie hmotného aj nehmotného kultúrneho dedičstva pre budúce generácie. O to významnejšie sú kultúrne pamiatky, v ktorých sa zlučujú obe tieto kategórie 
a ich dosah na lokalitu, kde sa nachádzajú, je velmi komplexný. Do tejto kategórie nesporne patria židovské synagógy na území Slovenska. Ich hodnota pramení v historickom odkaze, svojou transformáciou na kultúrne centrá výrazne vplývajú na život v súčasnosti a majú vel'ký potenciál určovat’ smer vývoja kultúry a komunitného života v budúcnosti.

Akustické vlastnosti týchto objektov významne vymedzujú ich celkový charakter. Výskum akustiky v predmetných synagógach na jednej strane dopĺňa doterajšie úsilie o ich komplexné zdokumentovanie, na druhej strane konkretizuje oblast' ich dalšieho využitia ako koncertných priestorov a pomáha pri vol'be optimálneho repertoáru pre verejnú reprodukciu. Vd’aka moderným technológiám merania ide o vel'mi efektívnu formu výskumu, nakol'ko využíva čisto neinvazívne metódy získavania dát, čiže integrita skúmaných objektov nie je nijako narušená. Eliminuje sa tým riziko prípadného znehodnotenia skúmaného objektu. Vytvorením akustických profilov predmetných synagóg pre použitie $v$ dozvukových softvéroch je možné prezentovat' ich kultúrny odkaz v globálnom rozsahu.

Obe skúmané ortodoxné synagógy, v Prešove a Košiciach, sú významnou súčast’ou historického odkazu židovskej kultúry na území Slovenska. Ich pôvodné zameranie však už nenachádza v súčasnosti plnohodnotné využitie. Reprofilizácia na koncertné sály je vel'mi efektívnym využitím ich potenciálu. Z výstupov realizovaného výskumu vyplýva, že architektonické dispozície aj akustické vlastnosti sú pre tento účel viac ako priaznivé. $V$ prípade synagógy $v$ Košiciach ide o úplnú transformáciu pôvodného účelu využitia na koncertnú sálu. Synagóga v Prešove plní aj funkciu múzea a v obmedzenom režime aj svoju pôvodnú funkciu. Výrazne však dominuje jej zameranie na komorné koncerty, ktorým sa prispôsobilo aj vybavenie interiéru. Z toho dôvodu ju vnímame ako koncertnú sálu.

Výstupy z realizovaných akustických meraní potvrdili správnost' tohto zamerania a užšie vyšpecifikovali ciel'ový repertoár vhodný pre tieto priestory. Zároveň môžu upútat' pozornost' zahraničných hudobných telies a produkčných spoločností, ktoré hladajú najvhodnejšie podmienky pre vytváranie zvukového záznamu interpretačných výkonov. Z pohladu komerčného využitia sa tým otvárajú nové možnosti samofinancovania týchto kultúrnych pamiatok a zvyšuje sa perspektíva na ich dôstojnú prevádzku a zachovanie.

POZNÁMKY

1 BERANEK, Leo: Concert Halls and Opera Houses: Music, Acoustics, and Architecture. New York: Springer, ${ }^{2} 2004,684$ s. ISBN 0387955240.

2 BARRON, Michael: Auditorium Acoustics and Architectural Design. Milton Park, United Kingdom: E \& FN Spon Press, 22010 , 504 s. ISBN 978-0419245100.

3 MARTELLOTTA, Francesco et al.: Guidelines for acoustical measurements in churches. In: Applied Acoustics, roč. 70, 2009, č. 2, s. $378-388$.
4 NEWHOUSE, Victoria: Site and Sound: The Architecture and Acoustics of New Opera Houses and Concert Halls. New York: The Monacelli Press, 2012, 272 s. ISBN 9781580932813.

5 United Nations Educational, S. a. C. O. In: Final Act of the Intergovernal Conference on the Protection of Cultural Property in the Event of Armed Conflict. Hague: UNESCO, 1954, $83 \mathrm{~s}$.

6 International Council on Monuments and Sites. In: International Charter for the Conservation and Restoration of Monuments 
and Sites (The Venice Charter 1964). Venice: ICOMOS, 1965, $4 \mathrm{~s}$.

7 Committee of Ministers. In: European Soil Charter. Strasbourg: Council of Europe, $1972,63 \mathrm{~s}$.

8 United Nations Educational, S. a. C. O. In: Convention Concerning the Protection of The World Cultural and Natural Heritage. Paris: UNESCO, 1972, $16 \mathrm{~s}$.

9 Committee of Ministers. In: European Charter of the Architectural Heritage. Strasbourg: Council of Europe, 1972, $4 \mathrm{~s}$.

10 Council of Europe. In: Convention for the Protection of the Architectural Heritage of Europe. Strasbourg: Council of Europe, 1985, 8 s.

11 International Council on Monuments and Sites. In: Charter for the Conservation of Historic Towns and Urban Areas (Washington Charter 1987). Washington: ICOMOS, 1987, $3 \mathrm{~s}$.

12 MARTELLOTTA, c. d., 2009, s. $378-388$.

13 HIDAKA, Takayuki - BERANEK, Leo - OKANO, Toshiyuki: Interaural cross-correlation, lateral fraction, and low- and high-frequency sound levels as measures of acous- tical quality in concert halls. In: The Journal of the Acoustical Society of America, roč. 98, 1995, č. 2, s. $988-1007$.

14 NEWHOUSE, c. d., 2012, s. $16-18$.

15 BORSKÝ, Maroš: Synagogue Architecture in Slovakia: Towards Creating a Memorial Landscape of Lost Community. Heidelberg: Hochschule für Jüdische Studien, 2005, s. 58.

16 BORSKÝ, c. d., 2005, s. $105-106$.

17 BORSKÝ, c. d., 2005, s. $69-77$.

18 BORSKÝ, c. d., 2005, s. $58-66$.

19 BORSKÝ, c. d., 2005, s. $74-75$.

20 BREZINA, Pavol - Peter ZAŤKO - JARABICA, Michal: Akustické vlastnosti vybraných ortodoxných synagóg na Slovensku. In: Fyzikálne faktory prostredia: Časopis o problematike fyzikálnych faktorov prostredia, roč. 9, 2019, č. 1, s. 9. ISSN 1338-3922.

21 Tamtiež.

22 Tamtiež.

23 BORSKÝ, c. d., 2005, s. 65.

24 BREZINA - ZAŤKO - JARABICA, c. d., 2019, s. 9.

25 Tamtiež.

Acoustic Properties of Concert Premises of Selected Slovak Synagogues in Prešov and Košice

This study deals with the acoustics of sacred objects (namely synagogues) which have been transformed to concert halls, or their original function has been expanded to embrace this purpose. It explains the reasons and process of transformation of sacred objects into concert halls. It accentuates the importance of the auditorium acoustics research within the preservation and maintenance of intangible cultural heritage. The author describes a specific method of measurement of acoustic attributes in closed spaces for concert purposes. He summarizes a wider social, urban, cultural and historical context of the construction of the studied objects. The study documents the architecture of the objects and its influence on their acoustic attributes. The author dedicates an increased attention to specific measurements in particular researched objects and to the evaluation of measured data. Finally it offers recommendations concerning an appropriate choice of music production in each particular object.

\section{Keywords}

auditorium acoustics research; acoustic measurements; acoustic profile; intangible cultural heritage; concert hall; synagogue 